\title{
Guidelines for dietary management of menopausal women with simple obesity
}

\author{
Anna Brończyk-Puzoń ${ }^{1}$, Dariusz Piecha², Justyna Nowak ${ }^{1}$, Aneta Koszowska ${ }^{1}$, Karolina Kulik-Kupka ${ }^{1}$, \\ Anna Dittfeld ${ }^{3}$, Barbara Zubelewicz-Szkodzińska ${ }^{1}$ \\ ${ }^{1}$ Department of Nutrition-Associated Disease Prevention, Faculty of Public Health, Medical University of Silesia in Katowice, Poland \\ ${ }^{2}$ Department of Obstetrics and Gynecology at St. Luke's Local Hospital in Piekary Śląskie, Poland \\ ${ }^{3}$ Doctoral Study in the School of Medicine with the Division of Dentistry in Zabrze, Medical University of Silesia in Katowice, Poland
}

\begin{abstract}
The problem of obesity affects all age groups. It is also observed among menopausal women. Menopause is the time in a woman's life when, as a consequence of hormonal changes occurring in the body, the risk of overweight and obesity increases significantly and, therefore, so does the risk of metabolic and cardiovascular diseases. Excess body weight in menopausal women may also be of social and psychological importance since the occurring symptoms may considerably decrease quality of life and sexual activity of these women. Reduction of body weight in obese menopausal women should play a vital role in treatment of this group of patients. Therefore, adequate management seems to be essential, and it should involve dietary, pharmacological and/or surgical treatment, depending on the patient's needs. Following a rational weight loss plan provided by a dietician under medical supervision may contribute to improvement of the health condition and quality of life. It is recommended to observe the guidelines on dietary management described in this article by adjusting a diet plan individually. The following work constitutes a review of articles from 2004-2014 which are available in the PubMed medical knowledge base and the Polish Medical Bibliography (Polska Bibliografia Lekarska). For this purpose, the following controlled vocabulary has been used: menopausal woman, menopausal diet, menopausal weight gain, menopausal weight loss, dietary management in menopause.
\end{abstract}

Key words: menopause, obesity, dietary management, menopausal women.

Obesity has been recognized as a worldwide epidemic of the $21^{\text {st }}$ century. Almost $65 \%$ of the world population lives in countries where excess body weight is the reason for higher mortality than underweight. In the period from 1980 to 2008 the number of obese people (body mass index, $\mathrm{BMI} \geq 30 \mathrm{~kg} / \mathrm{m}^{2}$ ) increased two-fold globally [1]. According to the data of the European Statistical Office (Eurostat), obese women aged 45-64 constitute $22.9 \%$ of women in the states of the European Union. The percentage of older obese women was three-fold higher than in the younger group of women aged 22-44. These data were published in 2008 [2]. According to the latest data of the World Health Organization (WHO), in Poland in 2010, the percentage of overweight women aged $30-100$ amounted to $62.6 \%$ and the percentage of obese women at the same age range amounted to $26.9 \%$. The average BMI for women aged 30-100 was $26.9 \mathrm{~kg} / \mathrm{m}^{2}$ [3]. The results of PolSenior project entitled "Medical, Psychological and Socioeconomic Aspects of Aging in Poland" published in 2012 provide the following information. In the group of 380 examined women aged $55-59$, it has been reported that $37.9 \%$ of them were diagnosed with overweight and $37.1 \%$ with obesity [4].
The methods used to determine body weight and its particular components differ in terms of techniques utilized and accuracy achieved. The most popular and simple methods to measure body weight and its particular components include anthropometry and bioimpedance analysis. More complex methods include dual-energy X-ray absorptiometry (DXA), magnetic resonance imaging, hydrostatic weighing, air-displacement plethysmography, a deuterium and bromide dilution method etc. The agreed obesity boundary value is $120 \%$ of the adjusted ideal body weight (AIBW), which corresponds to $\mathrm{BMI}=30 \mathrm{~kg} / \mathrm{m}^{2}$. Estimating the body fat percentage is said to be a more precise measurement of body weight than BMI. In normal conditions, body fat in adult women does not exceed $28 \%$ of the real body weight. Obesity is diagnosed when body fat exceeds $32 \%$ of the total body weight. In order to determine the influence of the excess body weight on an increased risk of particular diseases (e.g. circulatory system diseases), the method of measuring waist circumference is used. Waist circumference greater than $88 \mathrm{~cm}$ in women indicates abdominal obesity. A waist-to-hip ratio (WHR) reveals a positive correlation with the measurements of

Corresponding author: Anna Brończyk-Puzoń, Department of Nutrition-Associated Disease Prevention, Faculty of Public Health, Medical University of Silesia in Katowice, 18 Piekarska St., 41-902 Bytom, e-mail: anna.puzon@op.pl

To cite this article: Brończyk-Puzoń A, Piecha D, Nowak J, Koszowska A, Kulik-Kupka K, Dittfeld A, Zubelewicz-Szkodzińska B. Guidelines for dietary management of menopausal women with simple obesity. Prz Menopauzalny 2015; 14: 48-52.

Submitted: 8.07.2014; Accepted: 18.11.2014. 
the abdominal and peritoneal fat thickness estimated using other methods. It is calculated by dividing the waist circumference at the umbilicus $(\mathrm{cm})$ by the hip circumference at the superior iliac spines $(\mathrm{cm})$. The obtained value in women should not exceed 0.8. Values greater than 0.8 indicate android and abdominal obesity. Such adipose tissue distribution increases the risk of cardiovascular diseases [5].

During menopause the risk of developing obesity increases. Hormonal changes that occur in the menopausal period may contribute to higher accumulation of the adipose tissue, particularly within the abdominal cavity [6]. An increase in body fat results from decreased production of estradiol $\left(E_{2}\right)$ and body energy requirement which varies with age [7]. Visceral fat increase occurs in women as early as 3-4 years prior to menopause, manifesting a negative correlation with $E_{2}$ levels and a positive correlation with folliculotropic hormone levels (FSH) at the same time. Estrogens control lipolysis by increasing lipoprotein lipase activity of the adipose tissue or by increasing lipolytic activity of adrenaline [8]. The American Study of Women's Health Across the Nation conducted among 3257 women has revealed a negative correlation between $\mathrm{BMI}$ and the levels of $\mathrm{E}_{2}$ and $\mathrm{FSH}$ in premenopausal women and women at the early perimenopausal stage, as well as a positive correlation in the group of women at later perimenopausal and postmenopausal stages [9]. The research carried out on the animal models proves that the cessation of ovarian function increases body fat accumulation regardless of a diet being followed. Excess body weight in menopausal women is related to a higher risk of developing cardiovascular and metabolic diseases, as well as diminished quality of life and sexual potency [6]. The incidence of obesity among menopausal women is high. In the study by Dąbrowska et al. conducted among 136 women from the Silesian Voivodeship aged 45-65, the incidence scale of excess body weight in perimenopausal women was evaluated. Excess body weight was diagnosed in $60 \%$ of examined women, including obesity in $24 \%$ of them. The lowest body fat percentage was reported in women aged 45-50 (32.15\%), greater in women aged 51-60 (32.28\%), and the greatest in women aged 61-65 (35.5\%). Moreover, the research revealed a positive correlation between the body fat percentage and BMI $(p<0.0001)$, as well as a significant decrease in the body water percentage along with an increase in BMI $(p<0.01)$ [10]. The research by Kroemeke et al., which evaluated physical activity and body composition among 79 healthy postmenopausal women, emphasized that a correct BMI was observed only in the group of women with a significantly high level of physical activity, which meant going more than 12500 steps a day. Additionally, the research revealed statistically significantly lower values of BMI, WHR, body fat and visceral body fat in the group of women with the highest level of physical activity as compared with the other groups [11]. The results obtained by Zivkovic et al. being a part of the national cross-sectional epidemiological study on assessment of incidence of metabolic syndrome and obesity of Serbian women also confirm the above data. The group of 1075 women was subdivided into five groups: "premenopausal" $(n=95$, average age: $37 \pm 5.3$ ), "perimenopausal" ( $n=105$, average age: $47 \pm 4.6$ ), "early menopausal" ( $n=175$, average age: $54 \pm 4.5$ ), "late postmenopausal" ( $n=460$, average age: $58 \pm 8.8)$ and "geripausal" ( $n=240$, average age: $68 \pm 10.7)$. Abdominal obesity defined as a waist circumference greater than $80 \mathrm{~cm}$ has been diagnosed in each examined woman $(92 \pm 12.5 \mathrm{~cm})$. The average BMI amounted to $28.5 \pm 4.9 \mathrm{~kg} / \mathrm{m}^{2}$ [12]. In the study by Park et al. conducted in the group of 1422 Korean women aged 45-55, it has been found that there is a statistically significant difference in the average waist circumference between postmenopausal women and premenopausal women $(80.44 \mathrm{~cm}$ vs. $78.94 \mathrm{~cm})$. Moreover, the study has revealed statistically significantly higher values of systolic blood pressure (115.22 mmHg vs. 118.33 $\mathrm{mmHg}, p=0.003)$ and diastolic blood pressure (75.25 $\mathrm{mmHg}$ vs. $76.94 \mathrm{mmHg}, p=0.009)$, total cholesterol levels (189.39 mg/dl vs. $210.06 \mathrm{mg} / \mathrm{dl}, p<0.001)$ and triglycerides (111.91 mg/dl vs. $137.20 \mathrm{mg} / \mathrm{dl}, p=0.001$ ) in the group of postmenopausal women compared to premenopausal women [13]. Many studies describe increased risk factors for cardiovascular diseases, such as hypertension, dyslipidemia and hyperglycemia, as well as inflammatory markers. Furthermore, in the study by Jouyandeh et al., metabolic syndrome has been diagnosed in $30.1 \%$ out of 118 Iranian postmenopausal women. In the study the criteria of the report of Adult Treatment Panel III (ATP III) have been used [14]. The prospective cohort study by Elliasen et al. has shown an increased risk of breast neoplasm in women with body weight gain of $10 \mathrm{~kg}$ and more $(p=0.002)$ since the onset of menopause. On the other hand, body weight loss of $10 \mathrm{~kg}$ and more in postmenopausal women has diminished the risk of breast neoplasm $(p=0.01)$ [15].

\section{Obesity treatment}

The major goal of obesity treatment is to reduce body weight, diminish the risk of disorders associated with excess body weight and to prevent regaining the lost weight [16]. The studies show that the most effective method to prevent overweight and obesity during menopause is to follow a proper diet and do physical activity [17]. Following a low calorie diet constitutes one of the management stages when it comes to excess body weight, within which the following stages are included [18]:

1) non-pharmacological treatment, such as diet and physical activity, 
2) pharmacological treatment,

3) surgical treatment.

In the case of grade 1 obesity, treatment involves introducing a proper low energy diet, undertaking physical activity, changing lifestyle, and if the goal is not achieved, pharmacological treatment should also be implemented. In the case of grade 2 obesity, surgical treatment needs to be additionally provided, if a given individual suffers from concomitant diseases and the desired effects have failed to be achieved at earlier stages. As far as individuals with grade 3 obesity are concerned, they are subject to obligatory surgical treatment if the body weight loss has not been obtained by means of earlier stages of obesity treatment $[18,19]$. In the study by Mastorakos et al., a therapeutic approach regarding postmenopausal women has been presented. It should begin with a complex assessment of obesity, risk factors relating to cardiovascular diseases and other components of metabolic syndrome. The stages of obesity treatment are identical with the ones presented above [8].

\section{Diet}

Excess body weight is associated with numerous health risks, such as insulin resistance, type 2 diabetes (DM2), dyslipidemia, hypertension, cholelithiasis, some types of neoplasms, hepatic steatosis, gastroesophageal reflux, obstructive sleep apnea, gout and polycystic ovary syndrome (PCOS) [8]. It has been proved that $5 \%$ body weight loss compared with the original weight brings a number of health benefits, such as lower total cholesterol level, low-density lipoproteins (LDL-cholesterol) and lower triglycerides level. The subsequent outcome of following a suitable low energy diet also includes an increase in very high-density lipoproteins (HDL-cholesterol). Moreover, the examined individuals are observed with reduced hyperinsulinemia, decreased glucose level, as well as lower systolic and diastolic blood pressure that exceeded normal range values. General well-being and quality of life also improve [20].

An adequately prepared diet should meet all nutritional requirements in a suitable amount and proportion. It is recommended that body weight loss should not exceed $4 \mathrm{~kg}$ per month, i.e. it should stay within 0.5-1 kg per week. Following a diet with improper energy and nutrients supply may deteriorate health condition of the patient and decrease chances for permanent body weight reduction [18, 21]. Very low calorie diets (VLCD) - less than $800 \mathrm{kcal}$ daily - may be followed provided such a diet is ordered by a physician and is implemented under medical supervision $[22,23]$. The methodology to prepare a low energy diet consists of the following stages:

1. Estimating energy requirement - calculating basal metabolic rate (BMR) by means of the Harris-Benedict equation [24], equation by Mifflin et al. [25], or applying equations to calculate BMR used by experts of FAO, WHO, UNU dated 1985 and 2004 [26]. The equations are presented in Table I.

2. Estimating protein requirement $(0.8-1 \mathrm{~g} / \mathrm{kg}$ of adjusted ideal body weight [AIBW] or $20-25 \%$ of daily energy requirement).

3. Estimating fat requirement (20-25\% of daily energy requirement).

4. Estimating carbohydrates requirement (supplementation of energy requirement about $45-50 \%$ of daily energy requirement).

5. Determining food rations.

6. Dividing daily rations into meals.

7. Planning a menu (4-5 meals daily).

The followed low energy diet should also be a high fiber diet and eliminate high glycemic index foods $(\mathrm{Gl}<75)$. An optimal number of meals are 4-5 meals a day every three hours [21]. Daily protein intake should not be lower than $0.8 \mathrm{~g} / \mathrm{kg}$ of adjusted ideal body weight. The diet ought to be planned in such a way that additional $1.75 \mathrm{~g}$ of animal protein with high nutritional properties covers a deficit of $100 \mathrm{kcal}$. Total daily protein supply should be within $20-25 \%$ of daily energy requirement. Whilst the diet is being followed, fat energy supply should not exceed $30 \%$ of energy requirement. It should be noted that saturated fats ought to provide less than $7 \%$ of energy, polyunsaturated fats of n- 6 linoleic acid almost $8 \%$ of energy, and of $n-3$ about $2 \%$ of energy. The remaining amount of consumed fat should include monounsaturated fats (n-9). Carbohydrates supplement the diet, yet their amount should not be less than $130 \mathrm{~g}$ a day [27]. Fiber supply should be within 20-30 g daily, and soluble fiber should constitute $25 \%$ of it. During the diet, it is recommended to drink 2 litres of still water. In addition, table salt intake should be limited to $5 \mathrm{~g}$ a day $[18,21,28,29]$. Supply of vitamins and minerals should be in accordance with the standards of the Food and Nutrition Institute (Instytut Żywości $i$ Żywienia), which are currently binding in Poland [27]. Table II presents a sample menu dedicated to a menopausal woman with simple obesity.

Tab. I. Basal metabolic rate equation according to HarrisBenedict and Mifflin et al.

Estimating individual total energy requirement (total metabolic rate - TMR) by means of physical activity level (PAL) or nutritional standards. The level of physical activity that is low corresponds to PAL value in the range of 1.4 or 1.6 , moderate in the range of 1.75 or 2.0 and high in the range of 2.2 or 2.4 .

Estimating the amount of body weight reduction per time unit. In order for body weight to be reduced by $0.5-1.0 \mathrm{~kg}$ within a week, it is necessary to reduce energy supply by $500-1000$ kcal daily.

Final determination of a low energy diet level. Estimated daily energy deficit ( $\mathrm{kcal}$ ) should be deducted from total metabolic rate (TMR). The obtained value constitutes a caloric value of a diet. 
Tab. II. A sample menu dedicated to a menopausal woman with simple obesity

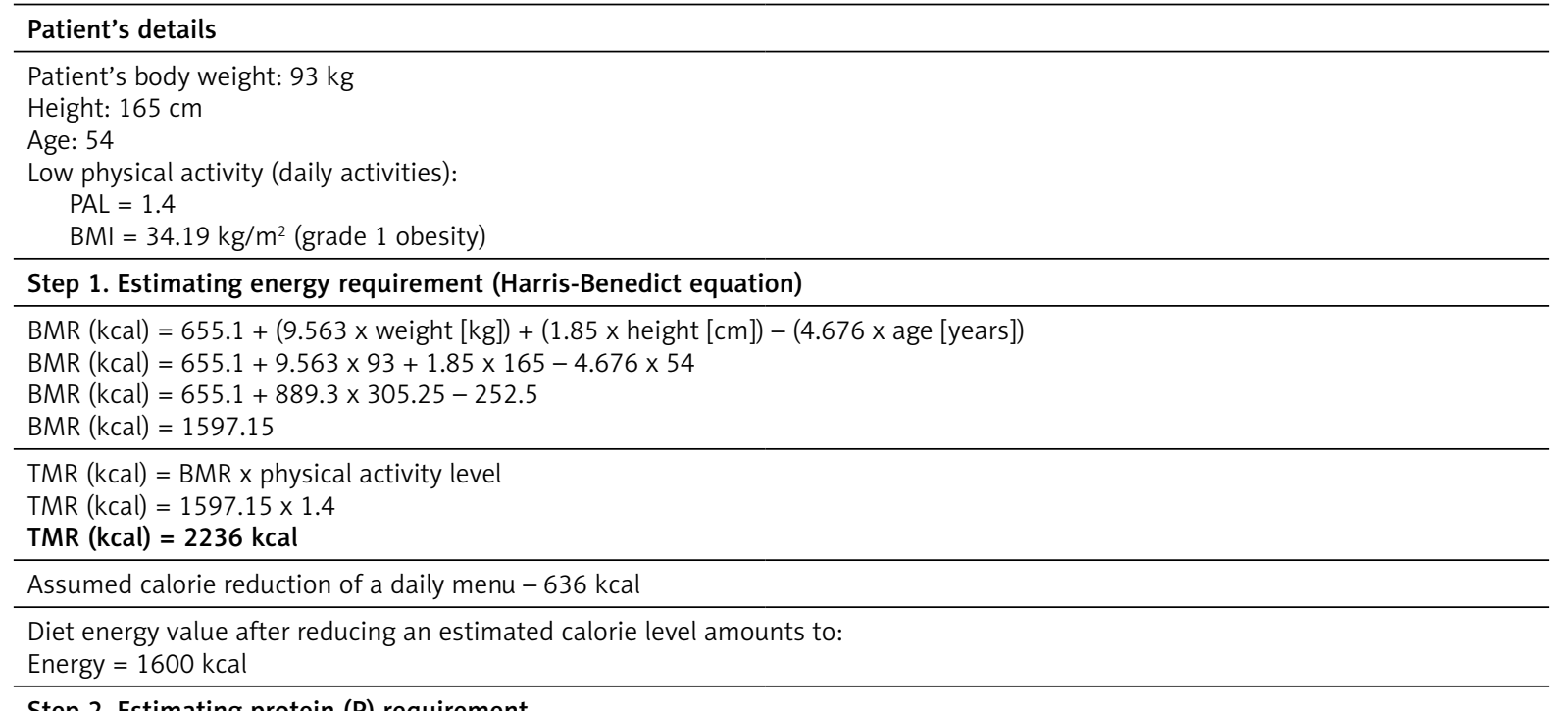

\section{Step 2. Estimating protein $(P)$ requirement}

Protein should constitute $20-25 \%$ of a diet energy value.

$\mathrm{P}=20 \% \times 1600 \mathrm{kcal}=320 \mathrm{kcal}$

$1 \mathrm{~g}$ protein $=4 \mathrm{kcal}$

$\mathrm{P}=320 \mathrm{kcal} / 4 \mathrm{kcal}=80 \mathrm{~g}$

\section{Step 3. Estimating fat $(F)$ requirement}

Fat should constitute $20-25 \%$ of a diet energy value.

$\mathrm{F}=25 \% \times 1600 \mathrm{kcal}=400 \mathrm{kcal}$

$1 \mathrm{~g}$ fat $=9 \mathrm{kcal}$

$\mathrm{F}=400 \mathrm{kcal} / 9 \mathrm{kcal}=44.5 \mathrm{~g}$

\section{Step 4. Estimating carbohydrates (C) requirement}

Carbohydrates supplement a diet energy value.

$C($ percentage $)=100 \%-(20 \%+25 \%)=100 \%-45 \%=55 \%$

$\mathrm{C}=55 \% \times 1600 \mathrm{kcal}=880 \mathrm{kcal}$

$1 \mathrm{~g}$ carbohydrates $=4 \mathrm{kcal}$

$\mathrm{C}=880 \mathrm{kcal} / 4 \mathrm{kcal}=220 \mathrm{~g}$

Dietary fiber: $30 \mathrm{~g}$

\section{Diet plan nutritional information}

\begin{tabular}{ll}
\hline Energy $=1600 \mathrm{kcal}$ & $1^{\text {st }}$ breakfast $25 \% \mathrm{kcal}=400 \mathrm{kcal}$ \\
Protein $=80 \mathrm{~g}$ & $2^{\text {nd }}$ breakfast $10 \% \mathrm{kcal}=160 \mathrm{kcal}$ \\
Fat $=44.5 \mathrm{~g}$ & Dinner $35 \% \mathrm{kcal}=560 \mathrm{kcal}$ \\
Carbohydrates $=220 \mathrm{~g}$ & Afternoon snack $10 \% \mathrm{kcal}=160 \mathrm{kcal}$ \\
& Supper $20 \% \mathrm{kcal}=320 \mathrm{kcal}$
\end{tabular}

Step 5. Preparing a sample menu

\section{$1^{\text {st }}$ breakfast:}

Chicken ham sandwich and a vegetable salad, unsweetened green tea:

whole grain rye bread ( $80 \mathrm{~g})$, butter $(10 \mathrm{~g})$, chicken ham $(40 \mathrm{~g})$

salad: butter head lettuce (60 g), tomato (100 g), cucumber (50 g), chive (5 g), linseed oil (8 g)

unsweetened green tea $(250 \mathrm{ml})$

\section{$2^{\text {nd }}$ breakfast:}

Fruit milk cocktail with bran:

Natural yoghurt (170 g), strawberries (150 g), wheat bran (15 g)

\section{Dinner:}

Creamy tomato soup with whole grain pasta, stewed chicken with vegetables and buckwheat:

Creamy tomato soup: carrot (50 g), parsley root (30 g), celery (20 g), leek (10 g), tomatoes (150 g), natural yoghurt (15 g), whole grain pasta (30 g)

Stewed chicken with vegetables and buckwheat: skinless chicken breast (100 g), rapeseed oil (10 g), courgette (50 g), red pepper (50 g), mushrooms (50 g), broccoli (50 g), cauliflower (50 g), garlic (5 g), buckwheat (50 g), mineral water (250 ml)

\section{Afternoon snack: \\ Fruit-flavored starch jelly:}

Fruit-flavored starch jelly (250 g)

\section{Supper:}

Sandwich with cottage cheese and smoked mackerel spread:

graham bread (60 g), cottage cheese (50 g), smoked mackerel (50 g), mineral water (250 ml) 


\section{Conclusions}

Menopause is a period when changes occurring in a woman's body may lead to body weight gain. At the same time, these changes are conducive to the development of diseases that are nowadays referred to as diseases of affluence. Therefore, adequate management seems to be essential, and it should involve dietary, pharmacological and/or surgical treatment, depending on the patient's needs. It is recommended to observe the guidelines on dietary management described in the above article by adjusting a diet plan individually.

\section{Disclosure}

Authors report no conflict of interest.

\section{References}

1. Obesity and overweight. Fact Sheets No 311. World Health Organization. Updated May 2014; http://www.who.int/mediacentre/factsheets/ fs311/en/

2. European Health Interview Survey. Eurostat news release; http:// epp.eurostat.ec.europa.eu/cache/ITY_PUBLIC/3-24112011-BP/EN/324112011-BP-EN.PDF

3. World Health Organization Global Infobase; https://apps.who.int/infobase/Indicators.aspx

4. Mossakowska M, Więcek A, Błędowski P. Pol-Senior. Aspekty medyczne, psychologiczne, socjologiczne i ekonomiczne starzenia się ludzi w Polsce. Termedia, Poznań 2012.

5. Tatoń J, Czech A, Bernas M. Otyłość. Zespół metaboliczny. Wydawnictwo Lekarskie PZWL, Warszawa 2007.

6. Davis SR, Castelo-Branco C, Chedraui P, et al. Understanding weight gain at menopause. Climacteric 2012; 15: 419-429.

7. Keller C, Larkey L, Distefano JK, et al. Perimenopausal obesity. J Womens Health 2010; 19: 987-996.

8. Mastorakos G, Valsamakis G, Paltoglou G, et al. Management of obesity in menopause: diet, exercise, pharmacotherapy and bariatric surgery. Maturitas 2010; 65: 219-224.

9. Randolph JF Jr, Sowers M, Bondarenko IV, et al. Change in estradiol and follicle-stimulating hormone across the early menopausal transition: effects of ethnicity and age. J Clin Endocrinol Metab 2004; 89: 1555-1561.

10. Dąbrowska J, Naworska B, Dąbrowska-Galas M, et al. Analysis of overweight and obesity in menopausal women using bioelectrical impedance analysis system. Prz Menopauzalny 2013; 17: 260-265.
11. Kroemeke A, Zając-Gawlak I, Pośpiech D, et al. Postmenopausal obesity: 12,500 steps per day as a remedy? Relationships between body composition and daily steps in postmenopausal women. Prz Menopauzalny 2014; 18: 227-232.

12. Zivkovic B, Vuksanovic M, Jelic MA, et al. Obesity and metabolic syndrome during the menopause transition in Serbian women. Climacteric 2011; 14: 643-648.

13. Park JK, Lim YH, Kim KS. Changes in body fat distribution through menopause increase blood pressure independently of total body fat in middle-aged women: the Korean National Health and Nutrition Examination Survey 2007-2010. Hypertens Res 2013; 36: 444-449.

14. Jouyandeh Z, Nayebzadeh F, Qorbani M. Metabolic syndrome and menopause. J Diabetes Metab Disord 2013; 12: 1-4.

15. Eliassen AH, Colditz GA, Rosner B, et al. Adult weight change and risk of postmenopausal breast cancer. JAMA 2006; 296: 193-201.

16. IASO SCOPE. Specialist Certificate of Obesity Professional Education. Materials from the Congress of the Polish Association for the Study of Obesity, Szczecin, 17 October 2009.

17. Godziejewska-Zawada M. Obesity and diabetes in menopause: prevention and therapeutic approach. Prz Menopauzalny 2013; 17: 5-9.

18. Pachocka L. Algorytm postępowania w leczeniu otyłości. Dietetyka 2008; 2: 13-15.

19. Szczepańska E. Postępy w leczeniu otyłości. Postępy Nauk Medycznych 2008; 3: 203-210.

20. Blackburn G. Effect of degree of weight loss on health benefits. Obes Res 1995; 3 Suppl 2: 211s-216s.

21. Jarosz M. Praktyczny podręcznik dietetyki. Instytut Żywności i Żywienia, Warszawa 2010.

22. Olszanecka-Glinianowicz M. Rola diety bardzo niskokalorycznej (VLCD) w leczeniu otyłości. Endokrynologia, Otyłość i Zaburzenia Przemiany Materii 2012; 8: 109-113.

23. Johansson K, Neovius M, Hemmingsson E, et al. Effects of anti-obesity drugs, diet, and exercise on weight-loss maintenance after a very-lowcalorie diet or low-calorie diet: a systematic review and meta-analysis of randomized controlled trials. Am J Clin Nutr 2014; 99: 14-23.

24. Harris J, Benedict F. A biometric study of basal metabolism in man. Carnegie Institute of Washington, Washington 1919.

25. Mifflin MD, St Jeor ST, Hill LA, et al. A new predictive equation for resting energy expenditure in healthy individuals. Am J Clin Nutr 1990; 51: 241-247.

26. Alfonzo-González G, Doucet E, Alméras N, et al. Estimation of daily energy needs with the FAO/WHO/UNU 1985 procedures in adults: comparison to whole-body indirect calorimetry measurements. Eur J Clin Nutr 2004; 58: 1125-1131.

27. Jarosz M. Normy żywienia dla populacji polskiej - nowelizacja. Instytut Żywności i Żywienia, Warszawa 2012.

28. Białkowska M. Leczenie dietetyczne - ciągle aktualna metoda terapii otyłości. Postępy Nauk Medycznych 2013; 5: 38-43.

29. Ciborowska H, Rudnicka A. Dietetyka. Żywienie zdrowego i chorego człowieka. Wydawnictwo Lekarskie PZWL, Warszawa 2012. 